of immunochemical reactions, and new structures for polypeptides and proteins. Last but not least, he combines with all his other talents a remarkable gift of exposition ; the impact of his work on the chemical world has been due largely to the brilliant lucidity of such treatises as "The Nature of the Chemical Bond".

\section{Memorial Tablet to Sir William Herschel}

ON November 8 a memorial tablet was dedicated to Sir William Herschel in Westminster Abbey, not far from the graves of Newton and of Sir John Herschel, the son of Sir William. Newton had been buried in the Abbey in 1727, but it appears that at the time of Herschel's death in $\mathbf{1 8 2 2}$ it had not been recognized that outstanding men of science should be buried there. From the epitaph on Herschel's grave at Slough, it is clear that his contemporaries realized that he had been one of the greatest astronomers of all time. He was known as the discoverer of the planet Uranus and of great numbers of double stars, star clusters and nebulæ. Some of these discoveries had been made when he was attempting to determine the distances of stars by their parallactic displacement; and although he had failed to determine the distance of any stars, he formed estimates which were not much in error. He had himself constructed telescopes of far greater power than any made by the instrument makers of that time for use in the national observatories, and the observations he made with these instruments made him the founder of sidereal astronomy on an observational basis. He was a pioneer in collecting and discussing astronomical statistics. $\mathrm{He}$ conceived our galaxy as the great flattened system it is. $\mathrm{He}$ determined the motion of the sun and planets through that system. He believed that some, at least, of the nebulæ might be island universes, that is, systems comparable with our own Milky Way but lying far beyond it. As there was no one with instruments comparable in light grasp with his, and no one with his great experience in observing, some of his ideas remained dormant until in the present century they could be taken up with the great Californian reflectors in combination with fast photographic plates.

The cost of the tablet in Westminster Abbey has been borne by Mr. J. E. Bullard, who had pointed out the absence of any memorial and the desirability of having one to the greatest of British observational astronomers. The service was conducted by the Dean of Westminster, Dr. A. C. Don, and an address on Herschel was given by Dr. J. Jackson, president of the Royal Astronomical Society.

\section{Royal Society Medal Awards for 1954}

THE following awards of medals have been made by the President and the Council of the Royal Society :

Copley Medal to Sir Edmund Whittaker, emeritus professor of mathematics in the University of Edinburgh, for his distinguished contributions to both pure and applied mathematics and to theoretical physics.

Rumford Medal to Dr. C. R. Burch, of the H. H. Wills Physics Laboratory, University of Bristol, for his distinguished contributions to the technique for the production of high vacua and to the development of the reflecting mieroscope.

Davy Medal to Dr. J. W. Cook, principal of University College, Exeter, recently regius professor of chemistry in the University of Glasgow, for his distinguished fundamental investigations in organic chemistry.

Darwin Medal to Dr. E. B. Ford, reader in genetics, University of Oxford, for his distinguished contributions to the genetical theory of evolution by natural selection, particularly in natural populations.

Hughes Medal to Mr. Martin Ryle, lecturer in physics, University of Cambridge, for his distinguished and original experimental researches in radio astronomy.

\section{Nature Conservancy :}

Scientific Research

Is an adjournment debate in the House of Commons on October 22, Mr. Geoffrey de Freitas, one of the two members of Parliament who are themselves members of the Nature Conservancy, directed attention to the work of the Conservancy, particularly to research work being carried out and the importance of both adequate finance and public understanding if the work of the Conservancy is to be effective. With regard to research, Mr. de Freitas said that, in accordance with a suggestion of the Waverley Committee in its report on coastal flooding, the Nature Conservancy has again investigated the possibility of using vegetation to stabilize the shifting coast-line and, in co-operation with the Somerset River Board, is experimenting in this way in Bridgwater Bay. In co-operation with the Agricultural Research Council and other bodies, it is also examining the effect of spraying roadsides to kill weeds. So far as the Conservancy can judge, spraying has not proved effective in killing the most troublesome weeds, and it appears that indiscriminate spraying is doing real damage to insect life and small fauna. Before the outbreak of myxomatosis in Britain a year ago, the Conservancy asked Mr. R. M. Lockley to investigate the matter, and his survey of the problem, its repercussions and the progress of the disease has proved a valuable guide. Mr. Lockley has concluded that the rabbit flea is the most important transmitter, and work is still being done in studying the consequence of the drastic reduction in the rabbit population on vegetation and animal life.

\section{Finance and Land Transference}

Apart from finance and the bearing of public relations on the prosecution of fundamental research, Mr. de Freitas raised the question of the policy of land transference in connexion with the Conservancy. Replying on the debate, Mr. J. R. Bevins, parliamentary secretary to the Ministry of Works, promised to bring before the Chancellor of the Exchequer the question of land transference and the use of the National Land Fund for the Nature Conservancy. $\mathrm{He}$ pointed out, however, that the Conservancy already possesses powers of compulsory purchase under the National Parks and Access to the Countryside Act, 1949, but these powers havo not been invoked and they are not to be used without the sanction of the Lord President of the Council. With regard to finance, the present annual expenditure of the Conservancy is about $£ 200,000$, and in this context Mr. Bevins stated that government expenditure on civil research is at the present of the order of $£ 20,000,000$ a year. Referring also to the ploughing up of sites of scientific interest, Mr. Bevins stated that the problems involved here are being discussed between the Nature Conservancy and the Ministry of Agriculture, and also with the National Farmers Union and the Council for the Preservation of Rural England. 